\title{
Investigation Process in Criminal Suspection Children on Theft by Weighting in SatReskrim Polrestabes Semarang
}

\author{
Adimas Dirgantara ${ }^{1}$
}

\begin{abstract}
The problem in this research are: the investigation process child suspects in criminal offenses of theft by weighting on Sat Reskrim Polrestabes Semarang, factors inhibiting the investigation of criminal theft by weighting with child actors in Semarang and Sat Reskrim Polrestabes solutions to obstacles investigation of criminal offenses of theft by weighting with child actors in Sat Reskrim Polrestabes Semarang. The methodology used by researchers is juridical empirical approach. While sources and types of data in this study are primary data obtained from field studies with interviews with investigators on Sat Reskrim Polrestabes Semarang. And secondary data obtained from the study of literature. Based on the results of studies that (1) the investigation process child suspects in criminal offenses of theft by weighting, while the act of investigation are as follows: Receiving Reports, Take First Action, arrest and detention, confiscation, examination of the suspect and witness, Termination of Investigation, completion of the investigation. (2) obstacles encountered by investigators in investigating the crime of theft by weighting with the perpetrator of children in Polrestabes Semarang certainly be affected by several factors that can facilitate or complicate and greatly affect the performance of members of the investigator to conduct an investigation (3) obstacles that arise in investigation in this case Polrestabes Semarang making efforts to overcome these barriers.

Keywords: Investigation Process; The Child Actors; Crime; Theft By Weighting.
\end{abstract}

\section{Introduction}

Children who are in the age of growth and development very often gets a bad influence on social relationships in the community. That places the behavior of children who do not fit the norm in society. Such behavior is categorized as a diversion to the norm commonly called community as a violation of the law, and even viewed as a crime. $^{2}$ Kids as part of a family, a baby, successors, and hope for his family. ${ }^{3}$

Conduct a study on children is interesting, considering the child as a human being who was always there between us, because as long as humans exist on the surface of the earth (in der welt sein). The position of the child in the legal environment as a subject of law, is determined from the shape and the legal system of the child as a group of people who are in legal status and classified as incapable or underage ${ }^{4}$. Given the unique characteristics and properties of the child and for the protection of children,

\footnotetext{
${ }^{1}$ Student of Master of Law, Universitas Islam Sultan Agung Semarang and Members of the Indonesian National Police (Polri) email dimdim.aza@gmail.com

2 Bambang Waluyo 2004 Pidana dan Pemidanaan Jakarta:Sinar Grafika p.1

3 Lilik Mulyadi 2005 Pengadilan Anak di Indonesia Teori Praktik dan Permasalahannya Bandung: CV.Mandar Maju p.103

${ }^{4}$ Maulana Hassan Wadog 2000 Pengantar Advokasi dan Hukum Perlindungan Anak Jakarta:PT.Grasindo p.3
} 
the case shall be tried at the Juvenile Juvenile Justice within the scope of the General Court. Juvenile justice process cases from the time of arrest, detention, trial, and further development must be done by a special officer who truly understand the problems of children. The rights of children in the criminal justice process should be understood as the embodiment of justice, but in practice is not the case. Another reason that in the face of children who have committed criminal acts, that mattered not whether these children can be punished or not, but what sort of action should be taken to educate the kids like it.

Countermeasures against various crimes both conventional and transnational crime are carried out by professional personnel who truly experts in their field and have practical experience related to the field it addresses. Legal protection proportionately much needed by society. Crime in the State of Indonesia is increasingly diverse types and mode. The last few years in 2014 is still developing criminal offense of theft by weighting and weighting are even today committed by children as a criminal theft by weighting and weighting. Deviant behavior of children is often referred to delinquency (juvenile delinquency). ${ }^{5}$

Criminal offenses committed by children or adults known as juvenile delinquency is more widespread and diverse, both the frequency and the quality of the seriousness of the crime. This is evident from the number of cases occurring among others fights, extortion / hold-up, torture and so on. Indonesian Child Protection Commission (KPAI) recorded 2,008 cases of crime committed school-age children during the first quarter of 2011. The amount includes various types of crime such as theft, riot, assault and sexual abuse committed students from elementary to high school. That number is increasing every year. In 2012 happened 2,413 criminal cases of school-age children, then in 2013 that as many as 2,508 cases. $^{6}$

Act No. 11 of 2012 on the Criminal Justice System to reinforce Kids on the definition of child in Article 1 paragraph (3) states that:

"Children in conflict with the law, hereinafter referred Children are over the age of 12 (twelve) years, but not yet the age of 18 (eighteen) years who allegedly committed crimes. Laws on Juvenile Justice saw the child on the act of doing, if the child committed a crime before the child is age twelve (12) years is not considered bad boy so that from a legal standpoint it can not be held accountable, the opposite of when reaching the age of 12 ( twelve) years to 18 (eighteen) years may be held accountable for the actions that he did, then when the child before the age of 18 (eighteen) years of married it is not categorized as a child and the judicial process through the public courts instead of juvenile justice, " 7

The provision of criminal sanctions against children as perpetrators of the crime of theft by weighting who have fulfilled the provisions of Article 363 paragraph (1) to 4, 5 of the Criminal Code and the consideration of judges in imposing criminal sanctions against children a criminal offense which is given is not intended to destroy the future children who have committed criminal acts. Imprisonment actually adversely affects a

\footnotetext{
${ }^{5}$ Santi Kusumaningrum 2014 Penggunaan Diskresi Dalam Proses Peradilan Pidana UI Press Jakarta p. 34

${ }^{6}$ Komisi Perlindungan Anak Indonesia-home page. http://www.kpai.or.id/berita/ kriminalitasanak/artikel.php. accessed on 11 September 2015 street vendors. 17:00 pm

${ }^{7}$ General Explanation of the provisions of Act No. 11 Of 2012 on Juvenile Justice System
} 
child's development. In Act No. 11 of 2012 on Child Criminal Justice System is currently pursuing the best form of punishment for children.

Under penalty against juvenile delinquents (juvenile delinquency) can be given action as provided in Article 82, paragraph (1) of Act No. 11 of 2012 on the Criminal Justice System Children who explained that:

- Actions that can be imposed on Children include:

- returns to the parent / Guardian;

- submission to someone;

- treatment in a mental hospital;

- LPKS treatments;

- the obligation to follow the formal education and / or training that was conducted by the government or private entities;

- revocation of a driver's license;

- repairs resulting from a criminal act.

- Measures referred to in paragraph (1) letter $d, e$, and $f$ subject to a maximum of 1 (one) year.

- Measures referred to in paragraph (1) may be filed by the Prosecution in its claim, unless a criminal offense punishable by a term of imprisonment of seven (7) years.

- Further provisions on the actions referred to in paragraph (1) shall be regulated by Government Regulation,

- Issue addressed in the child offender Criminal Polrestabes Sat Semarang in 2018:

- Theft by weighting Article 363 of the Criminal Code perpetrators of 4 people

- Theft with violence perpetrators Article 368 of the Criminal Code 1

- Persecution of Article 351 of the Criminal Code offenders 2

- Article 170 of the Criminal Code offenders pengeroyokan 2

Based on the background outlined above, the issues to be discussed in the writing of this study are: How is the child investigation suspects in criminal offenses of theft by weighting on Sat Reskrim Polrestabes Semarang?; What are the factors inhibiting the investigation of criminal theft by weighting with the child actors on Sat Reskrim Polrestabes Semarang ?; and How solutions to obstacles investigation of criminal offenses of theft by weighting with child actors in Sat Reskrim Polrestabes Semarang?

\section{Research Methods}

This study uses empirical juridical approach. What is meant by empirical juridical approach is an attempt to approach the issues examined by the nature of real law or in accordance with the reality of living in society. So research with an empirical approach should be done in the field, using methods and techniques of field research. Specifications of research used is descriptive analysis is to do a description of research findings with the data as complete and detailed as possible. Description of the purpose is to primary data and secondary data relating tolnvestigation process children in crime suspect theft by weighting Sat Reskrim Polrestabes In Semarang, Further analysis of the results of research by using legislation and relevant theory. 


\section{Results And Discussion}

\subsection{Investigation Process of Children Crime Suspection on theft by weighting in Sat Reskrim Polrestabes Semarang}

Before we know more about the process of sentencing against minors on the stages of the investigation, we will first talk about the notion of investigation itself.

According to Article 1 point 2 of the Criminal Code, which referred to an investigation is a series of actions the investigator in the case and in the manner set forth in this law to search for and collect evidence, the evidence is making light of crime that occurs in order to find the suspects. Under the draft itself known, there are two kinds of investigation authorities, the official Indonesian National Police (INP investigators) and officials of Civil Servants (PNS). For the case of criminal offenses committed by children in general are violated provisions of criminal laws in the Criminal Code, the investigation conducted by the investigator general that the investigating police. Investigators are police officers of the Republic of Indonesia for at least two auxiliary Lt. (Moda) Police (now Assistant Police Inspector of the two). ${ }^{8}$ Although the investigator is an investigator of the National Police but that does not mean investigators could Police investigating the case of a brat. In Act No. 11 of 2012 on Juvenile Court investigator known for their children, this is an authorized investigator conducting an investigation.

Based on interviews with M. Gargarin Friyandi, SIK ${ }^{9}$ Semarang Polrestabes investigators member while the investigation measures against the crime of theft by weighting in Polrestabes Semarang is as follows:

- Receiving Reports

- Take Action First

- Arrest and Detention

- Foreclosure

- The suspect and witness examination

- Termination of Investigation

- Completion of Investigation

After complete all necessary official report, the investigators submit the case file to the public prosecutor who is pernyerahan in the first stage is just berkasannya his case alone. In the case of investigations conducted by Polrestabes Semarang is considered finished, the investigator handed over responsibility for suspects and evidence the State Attorney Semarang. If the Kejari Semarang found the results of the investigations was less full, then immediately returned the documents Kejari Semarang the case to the investigator with instructions to include.

After the case file returned by the public prosecutor for equipped, the investigator shall immediately conduct an additional investigation in accordance with the instructions the prosecutor. Investigation deemed to have completion of the State Attorney Semarang if not returns the result of an investigation

\footnotetext{
${ }^{8}$ Ferry Anka Sugandar 2009 Bahan ajar Hukum Acara Pidana Universitas Pamulang Tangerang Pg 8

${ }^{9}$ Results of interviews with M. Gargarin Friyandi SIK on Tuesday July 102018 08:00 pm
} 
or if prior to deadline. The ending has been no notification about it from Kejari Semarang to investigators from Polrestabes Semarang.

\subsection{Factors Inhibiting the theft Investigation by weighting the Child Performers at Sat Reskrim Polrestabes Semarang}

KUHAP whose age has been more than a quarter century, feasible changes to conform to the development of science and technology and the development of community dynamics. Moreover, after the ratification of international conventions relating directly or indirectly to the law of criminal procedure. Various provisions in rail should be made part of the national legal provisions as part of its commitment to the provisions of ratified international.

Potential violations of the Criminal Procedure Code in the level of investigation of cases of theft by weighting that administrative and procedural violations in the investigation. Administrative violations in the level of inquiry and investigation can occur in the form of mild to the severe procedure.

Investigators in conducting an investigation into the crime of theft by weighting with child actors generally run smoothly, even if there are no obstacles that complicate obstacle for investigators these, however, can be overcome in practice.

There are obstacles encountered by investigators in investigating the crime of theft by weighting with child actors in Semarang Polrestabes certainly be affected by several factors that can facilitate or complicate and greatly affect the performance of members of the investigator to conduct an investigation. These factors include: ${ }^{10}$

- Number of Members Investigators Who Knows about the Act No.11 of 2012 on the amendment No. 3 of 1997 on the Child Criminal Justice System.

Number of members of the investigating child Semarang Polrestabes not all investigators know about the interrogation of minors terangka, in the case of the entry of theft by weighting with child actors settled within 15 (fifteen) days. With the number and timing of completion of a short case means that there is an element of time constraints in completing the investigation process until at devolved to the Public Prosecutor.

- The period of detention of suspects child.

According to one investigator Polrestabes Ragil Tri Wibowo Semarang, ${ }^{11}$ in accordance with the legislation of Article 33 paragraph (1) and (2) of Act No.11 of 2012 on the amendment - No. 3, 1997 specifies that for the purpose of investigation, the investigating authority to detain children in allege committed the crime (delinquency) based on preliminary evidence is strong enough. Arrests have been made if the child committed the offense call for imprisonment of 7 (seven) years and above or certain criminal offenses prescribed by the Act.

The term of detention for the purpose of investigation not later than 7 (seven) days, for the purpose of examination of unfinished can be extended a maximum of eight

\footnotetext{
${ }^{10}$ Adi Gesit Satata Investigator Polrestabes Semarang Personal Interview On Tuesday July 102018 hours: 09:00 pm.

${ }^{11}$ Results Interview with Ragin Tri Wibowo on Wednesday July 112018 at 09.00 pm
} 
days. And within a period of 15 (fifteen) days, the investigator should have submitted the case file to the public prosecutor. In this case, if a child is arrested or detained unlawfully (not fiiled terms that have been defined by the Act), then the child or his family or his lawyer may request an inspection by the judge about the validity of the arrest or detention in a pre-trial hearing.

In this case the investigators experienced problems very short time to do the investigation process with a total of 15 (fifteen) days, because in the process of investigation the investigator also must coordinate with BAPAS to conduct research what punishment the right to suspect a child in the case of theft by weighting. So that research results tehadap suspect child behavior can be maximized to determine the sentence in the Court's suggestion.

- Infrastructures Investigator to Conduct Investigations.

Means and has been met to conduct an investigation, whether it is HP, motorcycles, cars, computers, and a pistol, but in Polrestabes Semarang is currently no cell or a special detention room perpetrators of criminal offenses committed by children. As well as at present while in the process of investigation suspect the child was put together with adult offenders in cells.

Constraints in investigation of criminal theft by weighting with the perpetrator of children in Polrestabes Semarang seen from the number of members or personnel investigator who knows the process of investigation suspect child in case theft by weighting with offenders of children who only had time only within 15 (fifteen) days.

The period of detention of children in the process of investigation at the police level in accordance with Article 33 paragraph (1) and (2) of Act No.11 of 2012 on the amendment No. 3, 1997 has a first holding time of 7 (seven) days and may be extended for eight (8) days with a total of 15 (days) period of such detention must bestow investigator suspects and evidence to the General Attorney to do the trial process.

Within only 15 fifteen days in the investigation process is considered very less, because they have to coordinate with the relevant agencies such as BAPAS to do research on the background of children as perpetrators in the case of theft by weighting that is used to reference the prosecutors and judges in deciding punishment what is most appropriate for the child.

In Polrestabes Semarang for supporting infrastructure of the process investigation suspect a child in case of theft by weighting suffice just as well such as HP, motorcycles, cars, computers, and the gun but in Polrestabes Semarang not have room holding cell especially for children as perpetrators of crime, which has been child holding cell room is still the one with adult prisoners cell space. In this highly prone to interfere with the child's psychological detained when put together with adult offenders. ${ }^{12}$ (Interview investigators Ipda Dirga Abriawan, S.Tr.K on Wednesday, July 11, 2018 at 11:00 pm)

\footnotetext{
${ }^{12}$ Results Interview with Ipda Dirga Abriawan S.Tr.K on Wednesday July 112018 At 11:00 pm
} 


\subsection{Solution Against Barriers Investigation Crime of theft by weighting With Child Actors in Sat Reskrim Polrestabes Semarang}

In connection with the obstacles that arise in the investigation in this case Polrestabes Semarang making efforts to overcome these barriers as follows:

- Conduct training and seminars related to the crime of theft by weighting among law enforcement officers. Training and seminars regularly held an annual event that is held once a year, followed by the staff and investigators Unit Criminal Polrestabes Sat Semarang.

- Improving coordination and cooperation between Polrestabes Semarang with related agencies period of detention that are currently using Article Article 33 paragraph (1) and (2) Act No. 11 of 2012 which period of detention in the police investigation of the level of only 15 (fifteen ) returned setidanya days before the change in accordance with article 44 paragraph (1) Act No. 3, 1997 that investigators have a period of detention of children for 20 (twenty) days and can be extended ten (10) days. So by the time a total of 30 (thirty) days, the investigator nor can BAPAS maximum in the background mendalamai child committing the theft by weighting to determine what the appropriate punishment for children as perpetrators of crime.

- Sat Criminal Polretabes that coordination with units Semarang perform functions or provide advice to the leadership to do the construction or making room for perpetrators of cells separating children between criminals who are still children with adult offenders. So it does not diminish the rights of criminals, who are still children who still have a long future.

\section{Closing}

\subsection{Conclusion}

- The process of investigation of criminal theft suspect children carried out by investigators Polrestabes Semarang originated from reports of witnesses or victims of crime, followed by the issuance of a warrant investigation made by Sat Reskrim Polrestabes Semarang on behalf of the Chief Polrestabes Semarang which tells the investigator and the investigator maid to order an investigation into the crime of theft. Letter task orders made by Sat Reskrim Polrestabes Semarang ordered to investigators and investigators maid to perform the duties of investigation of the case given to him in the form of arrest, detention, seizure, for the purpose of investigation of the offenses in this study is the crime of theft by weighting performed by child,

- Barriers arising in the investigation of the crime of theft with child suspects conducted by investigators Polrestabes Semarang, among others:

- Lack of personnel investigator Polrestabes Semarang who knows the process of investigation and limited skills in handling criminal cases of suspected child against perpetrators of crimes who are still children.

- The period of detention of suspects children who are too short which inhibits the interrogation of suspects child. 
- The absence of special detention cells against perpetrators of crimes committed by children.

- How to overcome obstacles in the investigation of criminal suspects theft with children carried out by investigators Polrestabes Semarang is:

- Conduct training and seminars.

- Improving coordination and cooperation between Polrestabes Semarang with the agencies concerned.

\subsection{Suggestion}

- The investigation process should pay attention to the evidence that legitimate and that there can be optimized. The investigating authorities should attention to the impact caused by the criminal act theft suspect child. The need for efforts concrete to assist the implementation of investigations conducted by investigators, resulting in a snare suspect with Article legislation can be decided appropriately.

- Coordination with local authorities must be improved for their description of the agency is very helpful investigation so as not to cause problems in the execution of the investigation later.

- Investigators should anticipate the obstacles that arise in the process of investigation of the cases that go to Polrestabes Semarang including cases of theft by weighting so that these obstacles can be overcome with good.

\section{Bibliography}

[1] Adi Gesit Satata Investigator Polrestabes Semarang Personal Interview

[2] Bambang Waluyo 2004 Pidana dan Pemidanaan Jakarta:Sinar Grafika.

[3] Ferry Anka Sugandar 2009 Bahan ajar Hukum Acara Pidana Universitas Pamulang Tangerang

[4] General Explanation of the provisions of Act No. 11 Of 2012 on Juvenile Justice System

[5] Komisi Perlindungan Anak Indonesia-home page. http://www.kpai.or.id/berita/ kriminalitasanak/artikel.php. accessed on 11 September 2015 street vendors. 17:00 pm

[6] Lilik Mulyadi 2005 Pengadilan Anak di Indonesia Teori Praktik dan Permasalahannya Bandung: CV.Mandar Maju

[7] Maulana Hassan Wadog 2000 Pengantar Advokasi dan Hukum Perlindungan Anak Jakarta: PT.Grasindo.

[8] Results Interview with Ipda Dirga Abriawan S.Tr.K on Wednesday July 112018 At 11:00 pm

[9] Results Interview with Ragin Tri Wibowo on Wednesday July 112018 at 09.00 pm

[10] Results of interviews with M. Gargarin Friyandi SIK on Tuesday July 102018 08:00 pm

[11] Santi Kusumaningrum 2014 Penggunaan Diskresi Dalam Proses Peradilan Pidana UI Press Jakarta 